\title{
A COMPARATIVE STUDY OF THE ECOTOXICITY OF PALM-BASED METHYL ESTER SULPHONATES (MES) TO TILAPIA AND Daphnia magna
}

\author{
RAZMAH, G*; SITI AFIDA, I*; ZULINA, A M*; NOORAZAH, Z* and HAZIMAH, A H
}

\begin{abstract}
Methyl ester sulphonates (MES) is a surfactant derived from plant resources, suitable as active ingredient in detergents. MES possesses good surface-active properties, good detergency and tolerant to water hardness. In this study, the ecotoxicity of MES was evaluated through the 48 hr Daphnia magna immobilisation test and the $96 \mathrm{hr}$ fish acute toxicity test with Tilapia. MES samples with different alkyl chain lengths (C14, C16 and C16:18) produced by the Malaysian Palm Oil Board (MPOB) and commercial MES (C16:18) were tested. Results from all tests indicated that Daphnia was more sensitive to toxic effects from MES than was Tilapia. There is also significant difference in ecotoxicity responses for palm-based MES of various chain lengths regardless of the species tested. The ecotoxicity increased as the hydrophobicity of the MES increased due to increase of alkyl chain length. However, less than $30 \%$ of MES is used in detergent products and will not pose environmental effects on aquatic organisms. MES is therefore suitable for environmental compatible cleaning products in view of its ecotoxicity that is on par to the widely used anionic surfactants, such as linear alkylbenzene sulphonate (LAS). The use of MES in cleaning products may help the industry to fulfil its social responsibility to a cleaner and better environment.
\end{abstract}

Keywords: palm-based surfactant, acute immobilization test, freshwater invertebrate, fish; OECD; REACh.

Date received: 15 June 2016; Sent for revision: 16 July 2016; Received in final form: 9 August 2016; Accepted: 10 August 2016.

\section{INTRODUCTION}

A wide range of products and applications used by consumers and industry today contain surfaceactive agents, or shortly surfactants. Their use ranges from primary production processes to enhancing the quality of finished products. Therefore, surfactants are present in products such as motor oils, pharmaceuticals, cosmetics, detergents, and also in electronic printing, magnetic recording,

\footnotetext{
Malaysian Palm Oil Board,

6 Persiaran Institusi, Bandar Baru Bangi, 43000 Kajang, Selangor, Malaysia.

E-mail: razmah@mpob.gov.my
}

biotechnology, microelectronics and viral research (Rosen and Kunjappu, 2012). About 56\% of the overall demand for surfactants in 2014 accounted for cleaners and detergents for household segments (Ceresana, 2015).

Surfactants contributed a global turnover of 33.2 billion USD in 2014. Ceresana, a market research institute, predicted the annual revenues of surfactants to increase by $2.5 \%$ per annum to around 40.4 billion USD until 2022. The growth of the global surfactants market within 2015 to 2020 is estimated at a CAGR of $5.3 \%$ by volume and $5.5 \%$ by value. In 2014, the global market, in terms of volume, is dominated by the anionic surfactants segment with 7.7 million tonnes and followed by non-anionic 
surfactants with 6.3 million tonnes. Emerging markets especially in China, India and Brazil, as a result of new investments and projects, are predicted to boost the growth of surfactant market in the future (Marketsandmarkets.com, 2015).

Surfactants can be produced from both petrochemical (synthetic) and oleochemical (renewable) raw materials. The petrochemical feedstock is mainly derived from crude oil and converted to different surfactant intermediates, whereas oleochemical feedstock is commonly derived from plant oils (palm and coconut), plant carbohydrates (sorbitol, sucrose and glucose) and animal fats (tallow) (Holmberg et al., 2003; Rust and Wildes, 2008).

Methyl ester sulphonates (MES) are anionic surfactants derived from palm oil (Masuda et al., 1993; Salmiah et al., 1998; Chemithon, 2008) and their utilisation as a surface active agent offers several advantages including renewability, biodegradability, dispersion ability, detergency in hard water, high calcium tolerance and an ability to maintain enzyme activity (Matheson, 1996). The use of MES in commercial detergents started in the early 1990s in Japan (Masuda, 1995).

The technology to produce MES involves converting palm oil to methyl ester, followed by hydrogenation and later sulphonation of the ester. The feedstock used to produce MES in Malaysian Palm Oil Board (MPOB) is palm stearin (Zulina et al., 2006). Large companies, such as Lion Corporation (Japan), Stepan (USA) and Huish Detergent Inc. (USA), have been producing and using MES in their commercial cleaning products.

Zion Research (2014), in its latest report, highlighted the global market value and volume of MES was at 0.57 billion USD and 0.46 million tonnes, respectively. The market volume between 2015 and 2020 is projected to expand at CAGR of $18.6 \%$ to reach 1.58 billion USD by 2020 (Empowered News, 2015).

In 2014, Europe consumed over $40 \%$ of the MES market volume, followed by North America and Asia Pacific. It is projected that Asia Pacific will become the most rapid emergent market for MES in the future (Empowered News, 2015). According to Frost and Sullivan (2008), the market for MES is steadily growing, and more effort is being put to intensify its market potential by building product awareness. MES's exceptional potential to be used as environmental-friendly surfactant in detergents is seen as the driver for its growth. Its usage in this manner is beginning to be tapped due to the current demand for green and biodegradable raw materials in the surfactants market and this will eventually lead to potential high demand for MES.

Previously, the development of MES was stalled due to the lack of production facilities. Today, MES is gaining heightened interest as a result of its numerous benefits. MES outscores linear alkylbenzene sulphonates (LAS), a petroleumbased surfactant and currently the workhorse in detergent industry, in many areas. These include high purity, high activity levels, the absence of any volatile organic compounds, low di-salt content, gentleness on the skin and suitability for both liquid and powder detergents. In 2014, more than $40 \%$ share in global MES volume was consumed by the household detergents market. Personal care market was the second largest user for MES and this area is projected to show the highest market growth for MES in the future (Empowered News, 2015).

There is an increase in environmental concern over the use of chemicals in large volume as these chemicals may pollute the environment depending on their exposure period, persistence in the environment, and the behaviour of the affected organisms (Cunningham and Saigo, 1990). One of these chemicals is surfactant, where due to its widespread use, can be a potential toxicant when a large quantity enters the environment. Aquatic toxicity and aquatic behaviour are of major importance for surfactants since they are mainly released into the environment via wastewaters (Hrenovic and Ivankovic, 2007).

Aquatic toxicity, or ecotoxicity, is the study of the effects of a material on aquatic organisms at various trophic levels, from subcellular through individual organisms to communities and ecosystems. It is evaluated through the response of the affected aquatic organisms to the material (APHA, 1980). Ecotoxicity tests have become an essential element in the holistic evaluation of aquatic pollution. Nowadays, the chemical and physical tests are no longer sufficient to assess the potential effects of the material on aquatic organisms. Information associating chemical structure and ecotoxicity are important in explaining the effect of surfactants on aquatic and other organisms. Knowing which physico-chemical properties of a surfactant influence its toxicity could point to surfactants with minimal biological effects. Synthesis of new surfactants could also be guided by these findings.

There are different techniques to measure aquatic toxicity, both standard and screening, and the endpoint is often a $\mathrm{LC}_{50} \quad(50 \%$ lethal concentration) or an $\mathrm{EC}_{50}$ (50\% effect concentration). As the knowledge about surfactants' toxicity grew, different methods to test were developed, some of which were standardised by the Organisation for Economic Co-operation and Development (OECD), for example acute toxicity test on algae, on Daphnia magna and on fish (OECD, 1992).

This article is aimed at extending the knowledge, particularly regarding the effects of palm-based MES, upon non-target freshwater invertebrates and fish. Thus, in the present study D. magna and Tilapia were used to test the acute effects of palm- 
based MES, with the goal of comparing the acute toxicity of MES to organisms in two different trophic levels, leading to a discussion of the importance of evaluating the ecotoxicity behaviour of palmbased products in the aquatic environment and to demonstrate the environmental-friendliness of this surfactant.

\section{MATERIALS AND METHODS}

\section{Materials}

Palm-based MES (C14, C16 and C16/18:60/40) were manufactured using palm methyl esters in MPOB's MES plant. The palm stearin methyl ester feedstock is a typical sulphonation feedstock for use in laundry detergent formulations (Chemithon, 2008). Commercial palm-based MES (C16/18:60/40) was obtained from a local MES supplier and used for comparison. All samples contained more than $80 \%$ active content.

\section{Methods}

Fish acute toxicity test (OECD 203, 1992). The OECD 203 is a widely used test to evaluate the acute toxic effects of materials to aquatic organisms in short-term exposure and static conditions. The test method recommends seven freshwater fish to be used for testing, but, only Cyprinos carpio could survive in tropical freshwater.

Due to difficulty in obtaining this species locally, Oreochromis niloticus, or commonly known as Tilapia, a local freshwater fish, was used instead as it fulfilled most of the criteria for test species (APHA, 1980; OECD 203, 1992; Razmah and Salmiah, 2004; Razmah et al., 2006), i.e. ready availability throughout the year, easily maintained, convenience for testing, commonly presence throughout the country and previous experience has confirmed its suitability for ecotoxicity testing as per the OECD 203 Guidelines for Testing of Chemicals (1992).

The fishes, (2 to $5 \mathrm{~cm}$ ), supplied by a local fish supplier, were first acclimatised to the test conditions for a week. They were fed daily with commercial fish food. A day before the test, feeding was stopped and the fish were not fed during the bioassay.

The fish toxicity tests started with range-finding test $(24 \mathrm{hr})$ and then followed by definitive test (96 $\mathrm{hr}$ ). The range-finding test used concentrations in logarithmic series while the definitive test tested concentrations in geometric series. All concentrations were analysed in duplicate, including the control (without test substance), which was tested simultaneously (OECD 203, 1992; Razmah et al., 2006).

The acute toxicity of a substance to fish is expressed as the concentration that kills half of the fish exposed during the test, or $\mathrm{LC}_{50}$. Fish are considered dead if there is no visible movement and if touching of the caudal peduncle produced no reaction. The dissolved oxygen, temperature and $\mathrm{pH}$ of the water, and the number of dead fish were recorded at $24 \mathrm{hr}, 48 \mathrm{hr}, 72 \mathrm{hr}$ and $96 \mathrm{hr}$. The $\mathrm{LC}_{50}$ value is calculated via probit analysis with $95 \%$ confidence limits using SPSS (Statistical Package for the Social Sciences) software.

Daphnia sp., acute immobilisation test (OECD 202, 2004). OECD 202 test was conducted to assess the effects of palm-based MES towards Daphnia magna (D. magna), a freshwater water flea which is one trophic level lower than fish. D. magna has proven to be a simple and sensitive test species for predictive toxicity studies (Sandbacka et al., 2000). The young daphnids were exposed to various concentrations of the test substance for $48 \mathrm{hr}$ and the immobilisation, i.e. the inability of daphnids to resume swimming within $15 \mathrm{~s}$ after gentle agitation, were determined after $24 \mathrm{hr}$ and $48 \mathrm{hr}$, and compared with control values.

D. magna primary culture was obtained from the Fisheries Research Institute (FRI), Glami Lemi, Negeri Sembilan, Malaysia. The original stock culture was brought back from Ghent, Belgium. The culture was maintained in the test facility by periodical culturing.

The daphnids used in the test were less than $24 \mathrm{hr}$ old and only the third brood progeny was used to reduce variability. ISO 6341 (2012) even imposes that the test organisms should be at least third generation offspring and were derived from a healthy stock (i.e. showing no signs of stress such as high mortality, presence of males and ephippia, delay in the production of the first brood, discoloured animals, etc.). The daphnids used in a test were controlled to ensure that they were produced from cultures established from the same stock of $D$. magna. The stock of D. magna was maintained in the laboratory with conditions (light, temperature, medium) similar to those used in the test.

As with OECD 203, range-finding tests (24 hr) were initially conducted and based on the results obtained, a series of concentrations with a separation factor of less than 2.2 was used in definitive tests (48 hr). The highest concentration tested should result in total immobilisation of the daphnids while the lowest concentration tested should give no observable effect. These tests were conducted in triplicates (OECD 202, 2004) and each test beaker was observed at $24 \mathrm{hr}$ and $48 \mathrm{hr}$. Immobilised daphnids were removed immediately when observed. The $\mathrm{EC}_{50}$ value is calculated via probit analysis with $95 \%$ confidence limits using SPSS.

Analytical measurements. The $\mathrm{pH}$, temperature and dissolved oxygen were determined daily in each 
test and control solutions. The dissolved oxygen concentration in control and test beakers at the end of the test should be more than $3 \mathrm{mg}$ litre $^{-1}$ while the $\mathrm{pH}$ did not vary by $\geq 1.5$ units in any one test. In this study, the results were expressed based on the nominal concentration.

\section{RESULTS AND DISCUSSION}

The percentage of motionless D. magna or dead Tilapia in the control was determined within the test period to check the validity of the tests. According to test guidelines OECD 202 and 203, if the immobilisation of D. magna or the mortality of Tilapia exceeded $10 \%$, or the dissolved oxygen was less than $3 \mathrm{mg}$ litre $^{-1}$ in control and test solutions at the end of the test, or the variation in $\mathrm{pH}$ exceeded 1.5 units, the study would be considered invalid. However, these circumstances did not occur in both experimental set-ups. At the end of the tests, the immobilisation or mortality in the controls never exceeded $10 \%$, while the dissolved oxygen and $\mathrm{pH}$ also were within the stipulated range as required in the OECD guidelines. Thus, the toxicity tests were considered valid.

The acute tests were conducted on palm-based C14, C16 and C16:18 MES produced in MPOB, and commercial MES (C16:18). The ecotoxicity values for the four surfactants toward Tilapia and D. magna are exhibited in Table 1. The sensitivity of the local fish Tilapia was found comparable to those of the standard species normally used in ecotoxicity test (Razmah and Salmiah, 2004). There were insignificant differences in the ecotoxicities of the surfactants when tested on the local fish and the recommended fishes.

Table 1 shows that the $\mathrm{LC}_{50}$ and $\mathrm{EC}_{50}$ values of different chain lengths of MES to the same organism differed up to 10-fold for both Tilapia and $D$. magna. D. magna was more affected by ecotoxicity effects of MES than was Tilapia. The results exhibit significant differences in toxicity responses between structurally related palm-based MES irrespective

TABLE 1. ACUTE ECOTOXICITIES OF MES ON D. magna AND TILAPIA

\begin{tabular}{llllc}
\hline Result $^{* * *}$ & $\begin{array}{l}\text { C14 } \\
\text { MES }\end{array}$ & $\begin{array}{l}\text { C16 } \\
\text { MES }\end{array}$ & $\begin{array}{c}\text { 16:18 } \\
\text { MES }\end{array}$ & $\begin{array}{c}\text { Commercial } \\
\text { C16:18 MES }\end{array}$ \\
\hline $\begin{array}{l}\text { D. magna, EC } \\
(\text { mg litre }\end{array}$ & 77.6 & 1.15 & 0.77 & 0.76 \\
$\begin{array}{l}\text { Tilapia, LC } \\
(\text { mg litre }\end{array}$ & 22.6 & 12.6 & 1.41 & 1.41 \\
\hline
\end{tabular}

Note: *Three replicates, 10 daphnids/ concentration.

${ }^{* *}$ Two replicates, 10 fish/concentration.

*** With $95 \%$ confidence limit.

MES - methyl ester sulphonate. of the test species. The toxicity increased as the hydrophobicity of the MES increased due to increase in alkyl chain length. According to Boeije et al. (2006), the ecotoxicity of surfactants normally increases logarithmically with a linear increase in alkyl chain length.

The acute toxicity effects of palm-based and commercial C16:18 MES on D. magna and Tilapia were similar and the most toxic compared to the other MES samples. Previous ecotoxicity studies conducted using fish as test species (Razmah and Salmiah, 2004; Masuda et al., 1994) also showed an increase in toxicity values of MES with increase in carbon chain length. As observed by other researchers (Schoberl et al., 1988; Potokor, 1992; Fendinger et al., 1994), the possible reason for this is the greater interaction of the longer chain homologues with cell membranes (Ivankovic and Hrenovic, 2010). However, the reliance of the toxicity on the alkyl chain length is only applicable for compounds that are fully soluble in water. This may be due to lower bioavailability of longer chain homologues, as they have lower solubility (Garcia et al., 2001).

Although palm-based MES seemed to be moderately to highly toxic to aquatic organisms, their effects in the environment are harmless. Since only $10 \%-30 \%$ of MES is used in detergent products, equivalent to other commercial surfactants, palm-based MES will not cause environmental alarm. MES occurs mainly in the ionised form at environmental $\mathrm{pH}$ and as a result, it can be assumed that bioaccumulation is insignificant. The dilution in aquatic environment will cause the local predicted environmental concentration of MES to be very low (Razmah et al., 2006). In addition, risk assessment study conducted by Miura (2007) found that MES as 'low risk level' or of 'no concern' to the environment.

\section{CONCLUSION}

Considerable amounts of detergents used in the domestic and industrial domains are directly discharged into waterways. These may cause problems in the aquatic environment including toxicity of the surfactants to aquatic organisms, foaming, eutrophication, etc. Therefore, the surfactants used and released in large quantity into the environment are vital to be as innocuous as possible for the environment with low ecotoxicity and easily biodegraded.

Palm-based MES is a good and sustainable surfactant to be used in detergent formulations as an alternative to surfactants derived from petrochemicals. The results demonstrated considerable variation in ecotoxicity responses within structurally related palm-based MES regardless of the species tested. D. magna was found to be more sensitive to toxic effects from MES than 
Tilapia due to size of the test species. The toxicity increased as the alkyl chain length and resultant hydrophobicity of the MES increases. This trend was also observed in many other anionic surfactants. However, since less than $30 \%$ of MES is used in detergent products, palm-based MES will not pose environmental effects on aquatic organisms.

Hence, the use of palm-based MES in environmental-friendly detergent may help the detergent industry to fulfil its social responsibility to a cleaner and better environment. MES has good biodegradability and its ecotoxicity is better or comparable to the commercial, high volume anionic surfactants, such as LAS and sodium lauryl sulphate. The use of palm-based MES will help to stimulate Malaysia's agricultural economies and lessen the dependence on imported petroleumbased surfactants.

\section{ACKNOWLEDGEMENT}

The authors would like to thank the DirectorGeneral of MPOB for permission to publish this article. Thanks are also extended to members of the Ecotoxicology Laboratory, Advanced Oleochemicals Technology Division, MPOB for their technical assistance and support in this study.

\section{REFERENCES}

AMERICAN PUBLIC HEALTH ASSOCIATION (1980). Standard Methods for Examination of Water and Wastewater. Part 800, 15 ${ }^{\text {th }}$. Edn. p. 800-823.

BOEIJE, G M; CANO, M L; MARSHALL, S J; BELANGER, S E; VAN COMPERNOLLE, R; DORN, P B; GÜMBEL, H; TOY, R and WIND, T (2006). Ecotoxicity quantitative structure-activity relationships for alcohol ethoxylate mixtures based on substance-specific toxicity predictions. Ecotoxicology and Environmental Safety, 64: 75-84.

CERESANA (2015). Market study: surfactants ( $2^{\text {nd }}$ edition). http:/ / www.ceresana.com/en/marketstudies/chemicals/surfactants/, accessed on 2 November 2015.

CHEMITHON (2008). Methyl ester sulfonate the next generation surfactant. http: / / www.chemithon. com / Resources / pdfs / MES\% 20-20Next \% 20 Generation\%20Surfactant.pdf, accessed on 3 November 2015.

CUNNINGHAM, P C and SAIGO, B W (1990). Environmental Science, A Global Concern. Wm. C Brown Publishers, US. p. 1-622.
EMPOWERED NEWS (2015). Global fatty methyl ester sulfonates (FMES) market to be worth USD 1.58 billion by 2020. http: / / empowerednews.net/ global-fatty-methyl-ester-sulfonates-fmes-marketto-be-w orth-usd-1-58-billion-by-2020 / 1855759/, accessed on 2 November 2015.

FENDINGER, N J; VERSTEEG, D J; WEEG, E; DYER, $S$ and RAPAPORT, R A (1994). Environmental behaviour and fate of anionic surfactants. Environmental Chemistry of Lakes and Reservoirs (Baker, L A ed.). American Chemical Society, Washington. p. 528-557.

FROST and SULLIVAN (2008). Global methyl ester sulphonate market. http://www.frost.com/prod/ servlet / report-brochure.pag?id=P1A5-01-00-00-00, accessed on 4 November 2015.

GARCIA, M T; RIBOSA, I; GUINDULAIN, $\mathrm{T}$; SANCHEZ-LEAL J and VIVES-REGO, J (2001). Fate and effect of monoalkyl quaternary ammonium surfactants in the aquatic environment. Environmental Pollution, 111(1): 169-175.

HOLMBERG, K; JÖNSSON, B; KRONBERG, B and LINDMAN, B (2003). Surfactants and Polymers in Aqueous Solutions. Second edition, John Wiley \& Sons Ltd, West Sussex, England. p. 1-527.

HRENOVIC, J and IVANKOVIC, T (2007). Toxicity of anionic and cationic surfactant to Acinetobacter junii in pure culture. Central European J. Biology, 2(3): 405-414.

ISO 6341 (2012). Determination of the Inhibition of the Mobility of Daphnia magna Straus (Cladocera, Crustacea) - Acute Toxicity Test.

IVANKOVIC, $\mathrm{T}$ and HRENOVIC, J (2010). Surfactants in the environment. Arhiv Za Higijenu Rada I Toksikologiju, 61: 95-110.

MARKETSANDMARKETS.COM (2015). Surfactants market by product type (anionic, nonionic, cationic, \& amphoteric), by substrate type (synthetic, \& bio-based), by application (soap industry, personal care industry, textile industry, industry \& institutional cleaning, elastomers \& plastics industry, oilfield chemicals, crop protection, food industry, \& others) - trends \& forecast to 2020. http: / / www.marketsandmarkets.com / MarketReports/biosurfactants-market-493.html, accessed on 2 November 2015.

MASUDA, M; ODAKE, H; MIURA, K and OBA, K (1993). Biodegradation of 2-sulphonatofatty acid methyl ester ( $\alpha$-SFME). J. Japan Oil Chemists' Society (YUKAGAKU), 42(9): 643-648. 
MASUDA, M; ODAKE, H; MIURA, K and OBA, K (1994). Effects of 2-sulphonatofatty acid methyl ester $(\alpha$-SFME) on aquatic organisms and activated sludge. J. Japan Oil Chemists' Society (YUKAGAKU), 43(7): 551-555.

MASUDA, M (1995). Environmental aspects of detergent materials - biodegradation of detergent surfactants. Proc. of the $21^{\text {st }}$ World Congress of the International Society for Fat Research (ISF). Vol. 3. PJ Barnes and Associates. p. 649-653.

MATHESON, K L (1996). Surfactant raw materials: classification, synthesis and uses. Soaps and Detergents: A Theoretical and Practical Review (Spitz, L ed.). AOCS Press, Champaign, Illinois. p. 228.

MIURA, K (2007). Aquatic risk assessment of 2-sulfonato fatty acid methyl ester sodium salt (MES). J. Oleo Science, 56: 123-128.

OECD 203 (1992). Fish, acute toxicity test. OECD Guideline for Testing of Chemicals.

OECD 202 (2004). Daphnia sp., acute immobilization test and reproduction test. OECD Guideline for Testing of Chemicals.

POTOKOR, M S (1992). Acute, subacute and chronic toxicity data on anionics. Anionic Surfactants, Biochemistry, Dermatology (Gloxhuber, C and Kunstler, K eds.). 2nd ed. p. 81-116.

RAZMAH GHAZALI and SALMIAH AHMAD (2004). Biodegradability and ecotoxicity of palm stearin-based methyl ester sulphonates. J. Oil Palm Res. Vol. 16(1): 39-44.

RAZMAH GHAZALI; ZULINAABDUL MAURAD; PARTIBAN SIWAYANAN; MOHTAR YUSOF and SALMIAH AHMAD (2006). Assessment of aquatic effects of palm-based alpha-sulphonated methyl esters (SME). J. Oil Palm Res. Vol. 16(1): 225-230.

ROSEN, M J and KUNJAPPU, J T (2012). Surfactants and Interfacial Phenomena. $4^{\text {th }}$ Edn. John Wiley \& Sons, Inc., Hoboken, New Jersey. p. 1-616.

RUST, D and WILDES, S (2008). Surfactants: A Market Opportunity Study Update. OmniTech International Ltd., Midland, MI.

SALMIAH AHMAD; ZAHARIAH ISMAIL and JASMIN SAMSI (1998). Palm-based sulphonated methyl esters and soap. J. Oil Palm Res. Vol. 10 (1): 15-35.

SANDBACKA, $\mathrm{M}$; CHRISTIANSON, I and ISOMAA, B (2000). The acute toxicity of surfactants on fish cells, Daphnia magna and fish - a comparative study. Toxicology In vitro, 14: 61-68.

SCHOBERL, P; BOCK, K J; MARL and HUBER, L (1988). Data relevant to the ecology of surfactants in detergents and cleaning agents. Report on the State of Discussion in the Study-groups Degradation/ Elimination and Bio-testing of the Main Committee Detergents. Copyright of Carl Hanser Verlag, Munich.

ZION RESEARCH (2014). Global Fatty Methyl Ester Sulfonates (FMES) Market for Household Detergents, Personal Care Products and Other Applications, 20142020. p. 1-72.

ZULINA ABD MAURAD; RAZMAH GHAZALI; PARTHIB AN SIWAYANAN; ZAHARIAH ISMAIL and SALMIAH AHMAD (2006). Alpha-sulfonated methyl ester as an active ingredient in palm-based powder detergents. J. Surfactants and Detergents, 9(2): 161-167. 